\title{
Innovation, the diesel engine and vehicle markets: Evidence from OECD engine patents
}

\author{
David Bonilla \\ Oxford Martin School and Transport Studies Unit, School of Geography and Environment, Oxford \\ University, Oxford, OXI 3QY, UK \\ Justin D.K. Bishop \\ Engineering Department, University of Cambridge, Trumpington Street, Cambridge, CB2 1PZ,UK \\ Colin J. Axon \\ School of Engineering and Design, Howell Building, Brunel University, Uxbridge, London, UB8 3PH.UK \\ David Banister \\ Transport Studies Unit, School of Geography and Environment, Oxford University, Oxford OXI 3QZZ,UK.
}

This paper uses a patent data set to identify factors fostering innovation of diesel engines between 1974 and 2010 in the OECD region. The propensity of engine producers to innovate grew 1) after the expansion of the car market by 1.9 standard deviations, 2) following a shift in the EU fuel economy standard by 0.7 standard deviations, and 3) after a negative shift of loan rates by 0.2 standard deviations. The propensity to develop emissions control techniques was positively influenced by pollution control laws introduced in Japan, in the US, and in the EU, but not with the expansion of the car market. Furthermore, a decline in loan rates stimulated the propensity to develop emissions control techniques which were simultaneously crowded out by increases in publicly-funded transport research and development. Innovation activities in engine efficiency are explained by 1) market size, 2) loan rates and by 3) OECD diesel prices, inclusive of taxes. Price effects on innovation, outweigh that of the US corporate average fuel economy standards. Innovation is also positively influenced by increases in transport research and development in the past.

Keywords: corporate R\&D performance, economics of innovation, fuel efficiency, vehicle engines.

\section{Introduction}

The paper identifies the historical factors that influence firm innovation of diesel engines, with a focus on the EU, Japan and US markets in 1974 to 2010. Despite vast research on innovation, the relationships among environmental policy, publicly-funded transport research and development (R\&D) investment and patents, are not well known. Diesel engine innovation is closely linked to the car, truck and bus markets in Japan, the US, the EU, and China. ${ }^{1}$ A major benefit of rapid innovation is that the costs of climate policy for the transport sector can be lower than costs in the absence of innovation. Innovation can turn public R\&D, for energy efficient engines, into a cost effective investment.

\section{Background}

An innovation is defined by Freeman and Soete (1997) as the means of matching technical options to market opportunities through activities including experimental development and design, trial production, and marketing. An innovation can be either a product or a process. In the transport context, diesel engine technology is associated with poor air quality and with non- $\mathrm{CO}_{2}$ emissions, and for these two reasons improvements in pollution control technology have been sought. To improve air quality and non- $\mathrm{CO}_{2}$

\footnotetext{
${ }^{1}$ Amongst OECD countries, the fraction of diesel fuel in transport fuels, excluding rail and water, was $14 \%$ in 1973 rising to 34\% in 2010 (International Energy Agency, 2010) and growing at nearly four times the rate of gasoline consumption. In China, diesel accounts for $60 \%$ of fuel used in transport.
} 
Final version appeared as: D. Bonilla, JDK. Bishop, CJ. Axon, \& D. Banister (2014). Innovation, the diesel engine and vehicle markets: Evidence from OECD engine patents. Transportation Research Part D, 27, pp. 51-58, DOI: 10.1016/j.trd.2013.12.012.

emissions, the European Commission (EC) (European Commission, 2008) introduced the Air Quality Directive..In addition, diesel engines emit considerable amounts of $\mathrm{CO}_{2}$ (Bonilla, 2009), resulting in continued efforts to improve fuel efficiency. Figure 1 uses patent data to show technological changes of the diesel engine between 1974 and 2010.

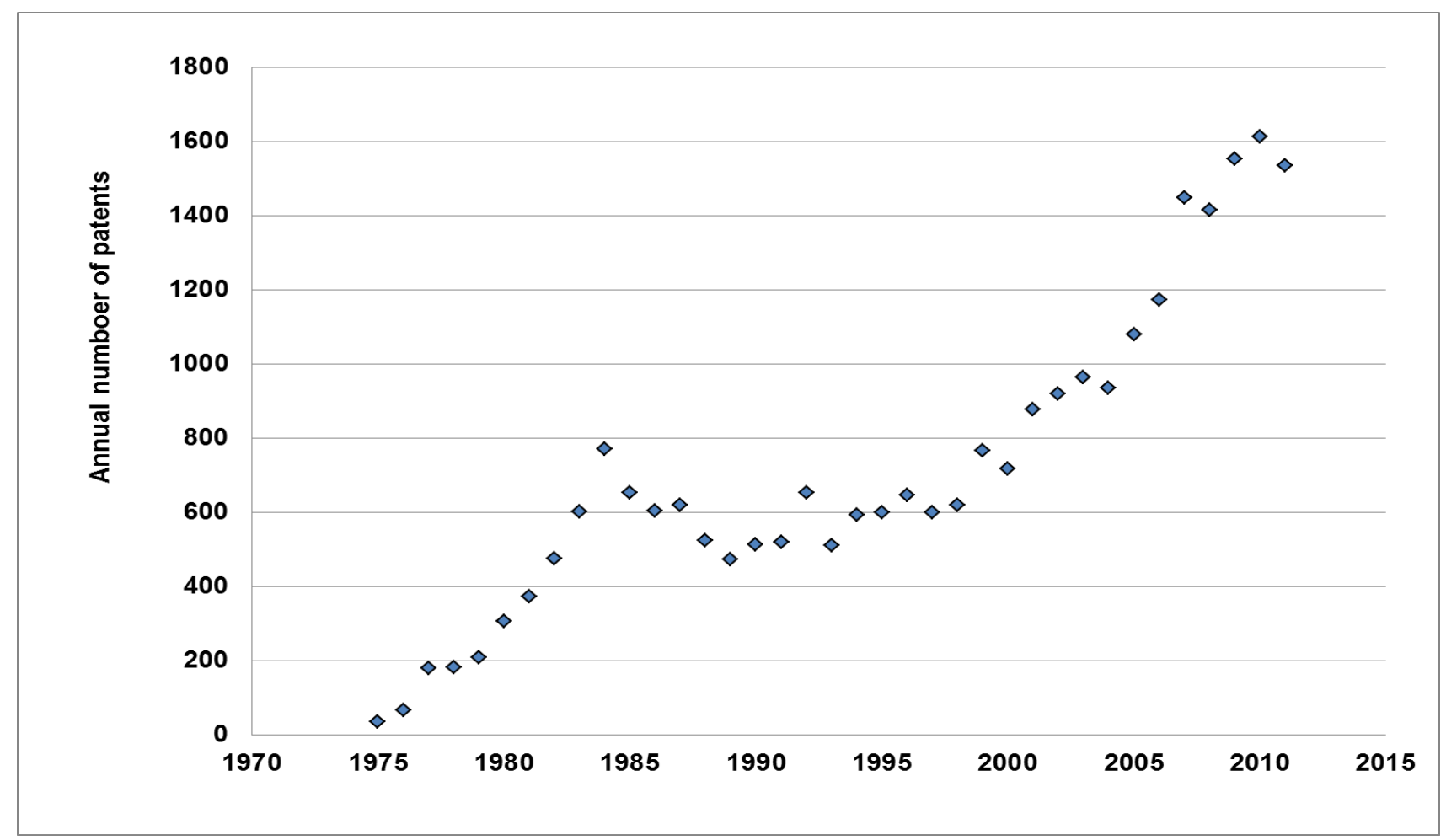

Note: Annual number of patents by date of publication.

Figure 1. Diesel engine patent counts: US, Japan, EU and rest of the world. Source: European Patent Office (2012).

Despite the continued rise in patent registrations (setting aside the hybrid diesel) there have been no radical innovations in vehicle engines for 50 years. There have been waves of incremental innovations and we focus on these in the context of environmental laws, air pollution standards and engine efficiency standards, based on the premise that these act as incentives for firms to find new, and cheaper, methods of reducing pollution (Porter, 1991). Our patent dataset covers these main diesel engine categories and considers diesel engine design and air pollution control innovation in Japan, US, and the EU.

We examined 26,378 patents registered between 1974 and 2010, most of which originate from independent inventors, car firms and components firms based in Japan, the EU and the US. ${ }^{2}$ Independent variables include measures of energy prices, three measures of market size, one metric of public R\&D expenditure, three metrics of NOx emissions limits, and two of vehicle fuel efficiency standards. The year of vehicle sales is lagged by two periods over 1978 to 2008. Three models are used. One tests whether the propensity to innovate responds to oil prices, to public R\&D expenditure, to standards of diesel engine efficiency, and more crucially to market size factors. The second tests if the propensity to innovate increases after the introduction of air quality laws in key OECD countries. The third considers factors explaining the growth of innovation in diesel engine efficiency.

Non- $\mathrm{CO}_{2}$ pollution standards are temporally correlated to both growth in patents and to the number of patent categories (Figure 2). Policy also has had a role. Besides the EC standard of 2008, non- $\mathrm{CO}_{2}$ pollution standards were introduced in the 1980s and 1990s, by the US, Japan, and the EU, with the latter being the least strict in part because it has a large diesel car stock. The timing of pollution standards was vital

\footnotetext{
${ }^{2}$ The data are grouped by 'diesel engine' categories and include innovations in diesel engine design, air pollution control.
} 
Final version appeared as: D. Bonilla, JDK. Bishop, CJ. Axon, \& D. Banister (2014). Innovation, the diesel engine and vehicle markets: Evidence from OECD engine patents. Transportation Research Part D, 27, pp. 51-58, DOI: 10.1016/j.trd.2013.12.012.

to raise the level of innovation of the diesel engine. These pollution standards are also linked to innovations that control exhaust gas emissions, (mainly NOx). ${ }^{3}$

Our analysis has its foundation in a number of prior studies, including that by the OECD (2009, 2011), of patents between 1965 and 2009. The OECD (2009) analysis found that fuel taxes play the largest role in diesel engine innovation, but omitted the effects of public and private R\&D funding. The US Environmental Protection Agency (2013) reports that many innovations in fuel injection and variable valve timing are major factors in fuel efficiency; fuel injection systems having replaced carburettors 20 years previously. These technologies are now being replaced by the direct injection system, particularly, in gasoline engines. Many studies find evidence that actions by public policy makers on non- $\mathrm{CO}_{2}$ and on $\mathrm{CO}_{2}$ emissions controls raise the innovation effort of firms (OECD, 2011; Hascic et al. (2009).

Two difficulties arise with these and similar studies 1) they rely on aggregate data on energy-related innovations, 2) they make no between national markets i.e. car sales, cost of capital, or the effects of public $\mathrm{R} \& \mathrm{D}$. We adopt a more disaggregate approach.

There is some evidence that pollution standards have affected the level of innovation of the diesel engine, although proving causality is difficult. The legislation may, for example, have simply coincided, for political reasons, with innovations that were reaching the market already.

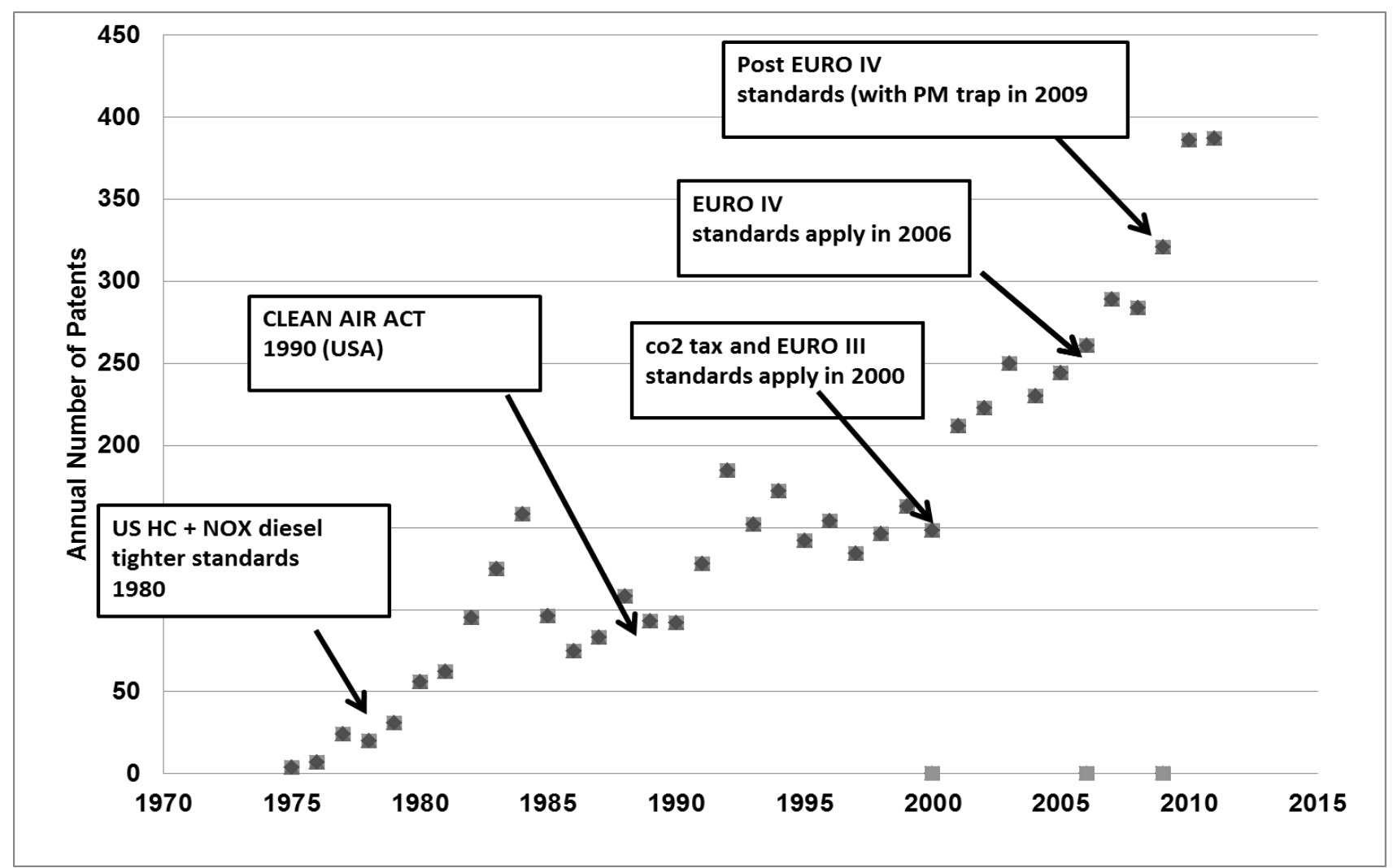

Note: counts by year of publication

Figure 2. Pollution control innovations for 'diesel and exhaust gas' engines. Source: European Patent Office (2012).

\footnotetext{
${ }^{3}$ Japan's NOx standard was introduced in 1974; the US NOx limits set in 1976; and the Euro NOx limit for diesel in 2000 (Hascic, et al., 2009). The first US non- $\mathrm{CO}_{2}$ standards, set in 1980, covered $\mathrm{HC}$ and the $\mathrm{NO}_{\mathrm{x}}$ diesel emissions and led to significant increases in innovations. The US Clean Air Act of 1990 also led to rapid innovation in pollution control. A series of pollution controls introduced in the EU (Euro III) had a similar effect (Lutsey, 2012).
} 
Final version appeared as: D. Bonilla, JDK. Bishop, CJ. Axon, \& D. Banister (2014). Innovation, the diesel engine and vehicle markets: Evidence from OECD engine patents. Transportation Research Part D, 27, pp. 51-58, DOI: 10.1016/j.trd.2013.12.012.

\section{Approach}

Our focus is not on radical innovation but on incrementalism - innovation that does not result in breaks with past technological patterns. The types of innovations that we considered is based on OECD (2009):

- air to fuel ratio,

- electronic fuel injection,

- engine management systems, on-board diagnostics, and sensors,

- ignition timing, variable valve timing, variable compression ratio, combustion chamber geometry,

- engine performance during cold start acceleration,

- combustion, air and fuel conditioning.

Data on patents is taken from the European Patent Office (2012) that is accessed through ESPACE. This contains data from more than 90 countries. Our search strategy used international patent (IPC) codes to identyfy keywords and returned three categories of innovations as well as subfields (Figure 3). The patents are sorted by year of publication to ensure that only successful ones are included. Figure 3 also compares innovations by category between 1982 and 2010. The share of combustion patents, mostly involving engine efficiency, increases between 1982 and 1990, coinciding with two peaks of public R\&D funding: 1980 and 1985 (Figures 2 and 4). Engine efficiency innovations peak in 1990, and by 2010 they are largest contributor to engine innovation. Engine efficiency performance is negatively correlated to the adoption of the catalytic convertor and the introduction of tighter exhaust gas regulations (OECD, 2009). ${ }^{4}$ Figure 3 also shows that the share of pollution abatement patents fell between 1995 and 2010, while that of input fuels patents is small. The main source of innovation was engine efficiency rather than improvements in pollution control between 1990 and 2010 .

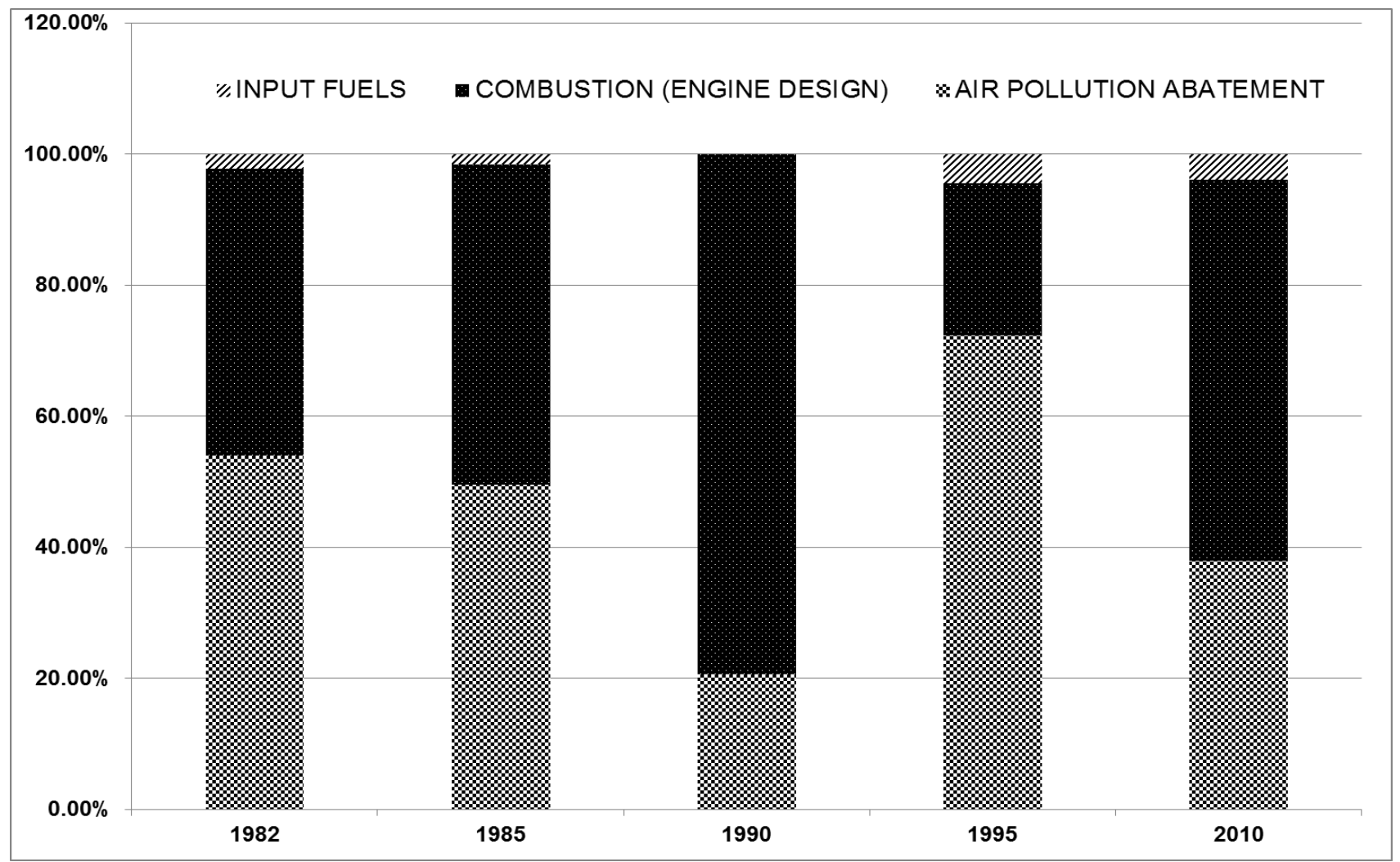

Figure 3. Innovations for diesel vehicle engines. Source: European Patent Office (2012).

\footnotetext{
${ }^{4}$ Diesel engines have higher non- $\mathrm{CO}_{2}$ emissions than gasoline engines, however, the latter are less fuel efficient.
} 
Final version appeared as: D. Bonilla, JDK. Bishop, CJ. Axon, \& D. Banister (2014). Innovation, the diesel engine and vehicle markets: Evidence from OECD engine patents. Transportation Research Part D, 27, pp. 51-58, DOI: 10.1016/j.trd.2013.12.012.

Figure 4 shows the volatility of publicly-funded transport R\&D between 1974 and 2010. The effect of transport R\&D funding on innovation generally involves time lags that increase the uncertainty of patenting activity.

The transport R\&D measure includes labour and capital expenditures, but excludes some scientific and technical activities. Transport R\&D growth matches that of engine efficiency patents in the last decade (Figure 4) and shows that $97 \%$ of publicly financed transport R\&D takes place in a small number of countries. The subcategory of 'on-road vehicles' within the 'transport R\&D' category is the largest fraction. The R\&D data has two disadvantages: first, disaggregated data for transport R\&D categories are only available for 2009-10; and secondly, the R\&D statistics in Figure 4 exclude private expenditure which is important in Japan and the EU.

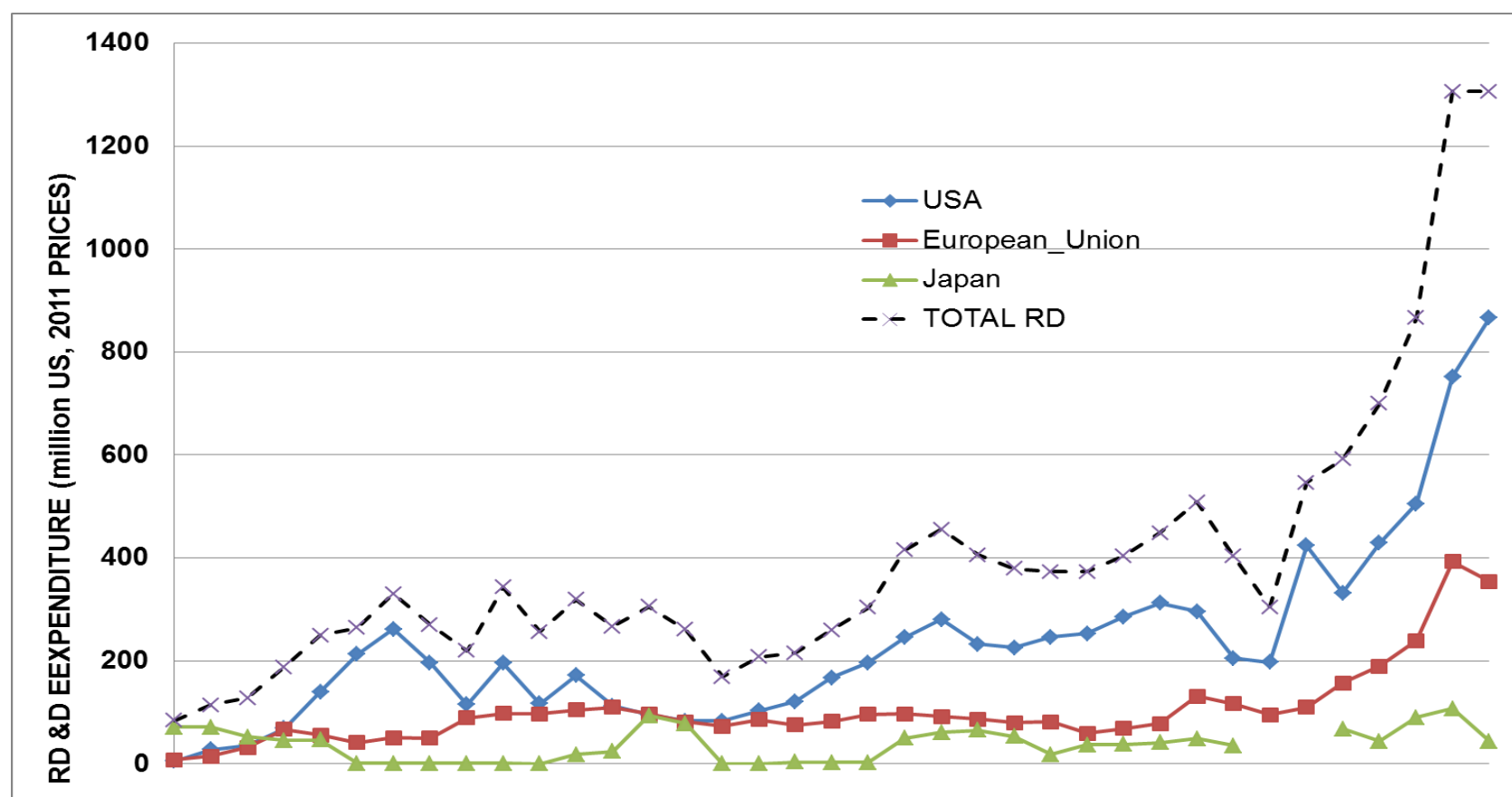

1974197619781980198219841986198819901992199419961998200020022004200620082010

Note: Data are in \$million in constant 2011 prices and exchange rates. The EU in this context includes 21 nations. Transport RD is classified by the International Energy Agency (2011a) as including categories of RD for 'on road vehicles', 'vehicle batteries', 'advanced power electronics', 'motors', 'advanced combustion engines', 'electric vehicle infrastructure', 'fuel for on-road vehicles' 'material for on road vehicles', 'unallocated transport', 'off road transport and transport systems', as well as other transport. The IEA does not report a breakdown for RD investment of these classifications for all years but the 'on road vehicles' is the main item in 2010.

Figure 4. Public funding for R\&D in transport between 1974 and 2010 for the OECD countries. Source: International Energy Agency (2012).

After the US, the key countires in transport R\&D funding are Japan and Germany with South Korea and China becoming increasingly important (not shown in Figure 4). For private firms, the incentive to innovate can stem from the need to compete in new product markets, to reduce costs of energy use, or from the need to reduce the effect of high energy prices. Historically, the US has shown the largest public R\&D expenditure, but this has been volatile with peaks in 1990, 1995, 2005, and 2010-11. These peaks correlate with high oil prices. ${ }^{5}$ The increase in US public R\&D funding in recent years may also be due to the introduction of the American Recovery and Reinvestment Act in 2009 (Yergin, 2011).

\footnotetext{
${ }^{5}$ Transport R\&D expenditure accounts for $17 \%$ of the R\&D energy budget for the US; $1 \%$ for Japan and $6 \%$ for the EU in 2010 (IEA, 2012)
} 
Final version appeared as: D. Bonilla, JDK. Bishop, CJ. Axon, \& D. Banister (2014). Innovation, the diesel engine and vehicle markets: Evidence from OECD engine patents. Transportation Research Part D, 27, pp. 51-58, DOI: 10.1016/j.trd.2013.12.012.

Figure 5 provides patent counts for 1974 to 2010 against diesel vehicle sales in the EU. The data series move in tandem because innovators will be influenced by the expected market size; Europe is the largest diesel private car market in the world. The data are based on the published patents 18 months after they are filed. Thus, microeconomic events that occur prior to a patent application can influence decisions to innovate. It takes four years for an inventor to be granted a patent.

Popp (2002), Hascic et al. (2009), Crabb and Johnson (2007) and Newell et al. (1999) have found expected oil prices to be a primary motivator of innovations. Oil prices were relatively stable in the $1980 \mathrm{~s}$ and 1990s but by the early 2000s, had quintupled with engine efficiency patents growing simultaneously.

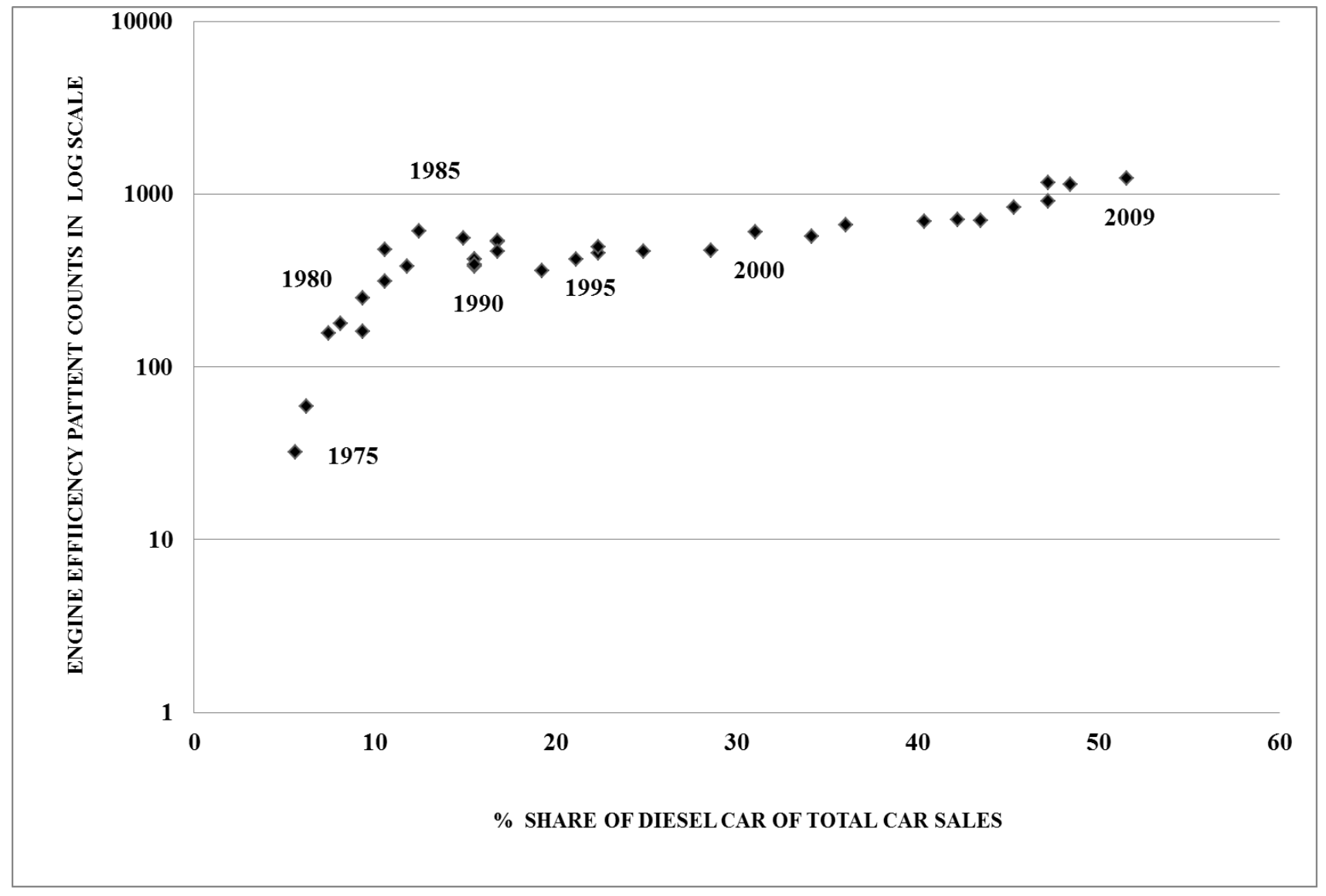

Figure 5. Annual patent activity and the share of diesel car sales lagged one year for European Union data. Source: European Patent Office (2012), Joint Research Center (2002) and Eurostat (2012). 
Final version appeared as: D. Bonilla, JDK. Bishop, CJ. Axon, \& D. Banister (2014). Innovation, the diesel engine and vehicle markets: Evidence from OECD engine patents. Transportation Research Part D, 27, pp. 51-58, DOI: 10.1016/j.trd.2013.12.012.

\section{Method}

Table 1 lists the input data used in our econometric analysis. Between 1974 and 2010, patenting activity, mostly in Japan, the EU and the US, averaged 693 patents a year. On average, engine efficiency innovations accounted for $79 \%$ of all diesel patents at a time when oil prices were $\$ 33$ a barrel (average diesel of $\$ 0.94$ a litre); and an average of two million trucks were sold in Japan and 5.8 million in the US. On average, $23 \%$ of passenger car sales in Europe were powered by diesel in this period.

Table 1. Summary of data used, 1974 to 2010.

\begin{tabular}{lccc}
\hline Variable Name and Units & Median & St. Dev. & Maximum \\
\hline Diesel patents (US, Japan and EU) & 693 & 421 & 1612 \\
Patents: engine design (fraction of diesel engine patents; US, Japan \& EU) & 0.79 & 0.05 & 0.89 \\
Patents counts: pollution control (fraction of diesel engine patents; US, Japan & 0.20 & 0.05 & 0.30 \\
$\quad$ \& EU) & & 0.41 & 1.90 \\
Diesel prices (\$/litre using purchasing power parity). With tax included) & 33 & 22 & 97 \\
OECD average oil price (\$ 2011 prices). & 113 & 172 & 450 \\
NOx standard (parts/million) (Japan) & 3.34 & 2.70 & 9.00 \\
Japan discount (loan) rate (Bank of Japan) (\%) & 5.62 & 2.99 & 13.16 \\
US Treasury bill rate (secondary market discount basis) (\%) & 0.40 & 0.49 & 1.00 \\
EU voluntary agreement on fuel efficiency (dummy variable) & 20.67 & 1.42 & 24.20 \\
CAFE (miles/gallon) & 313 & 239 & 1135 \\
Public R\&D funding & & 59
\end{tabular}

Sources: Diesel and engine design patents: European Patent Office, 2012); diesel and oil prices (International Energy Agency, 2011b); EU Voluntary Agreement (OECD, 2009); RD funding in transport (International Energy Agency 2012); loan rate Japan (Bank of Japan, 2012); US loan rate (US Federal Reserve, 2012); trucks and buses sales in Japan (Japan Automobile Manufacturers Association, 2012; IEEJ, 2010); sales of US trucks (Transportation Energy Data Book, 2011, Davies and Diegel, 2011); EU sales of diesel cars (Joint Research Center, 2003; Eurostat, 2012). CAFE data (US Department of Transportation, 2012). NOx data (OECD (2009).

Our first two models represent the propensity of firms to innovate in terms of engine efficiency and pollution control technologies, while the third estimates factors influencing the growth of car firms' innovative activity in engine efficiency between 1984 and 2010. The data were ordered using Excel's pivot option to visualise the entire set of patent information. Patent data was obtained for each IPC (international patent classification) of patent, and the company owning the patent. ${ }^{6}$ All three models mainly focus on innovations by private firms. Equation 1 summarises the hypothesized relation between innovation, public R\&D, fuel economy standards, market size, diesel price and loan rates, for 1974 to 2008 . We expect positive coefficients $(\beta)$ except for the LoanR variable. The model used is:

$$
\begin{aligned}
& \text { epat }_{t} /_{\text {totdiesel }}, \quad=\alpha+\beta_{1}\left(P U B R \& D_{t-1}\right) \\
& +\beta_{2}\left(\text { oilp OECD }{ }_{t}\right)+\beta_{3}\left(\text { EUSales }{ }_{t}\right) \\
& +\beta_{4}\left(\text { JPSales }_{t}\right)+\beta_{5}\left(\text { EUVA }_{t-1}\right)+\beta_{6}\left(\text { LoanR }_{t}\right) \\
& \left.+\beta_{7} \text { (time trend }\right)+\varepsilon_{t}
\end{aligned}
$$

\footnotetext{
${ }^{6}$ The ESPACE database (European Patent Office, 2012) provides IPC codes used to order the data for pollution control innovations and engine design.
} 
Final version appeared as: D. Bonilla, JDK. Bishop, CJ. Axon, \& D. Banister (2014). Innovation, the diesel engine and vehicle markets: Evidence from OECD engine patents. Transportation Research Part D, 27, pp. 51-58, DOI: 10.1016/j.trd.2013.12.012.

where, epat is the annual percentage of successful diesel engine efficiency patents of total diesel engine ones (totdiesel); $R \& D$ is funding in transport R\&D in the OECD; oilpOECD is oil prices in the OECD; EUSales is the ratio of diesel car sales to total car sales; JPSales is the sale of truck and buses in Japan; EUVA is European Union Voluntary Agreement for fuel efficiency ( 1 for 1995 to 2008; 0 otherwise); LoanR is the loan rate in Japan; $t$ is a continuous time tend; and $\varepsilon$ is the error term. Annual data is used throughout. The coefficients are epected to be positive except for the cost of captial in the US (FedUS).

Equation 2 is used to estimate the propensity to innovate in pollution control techniques from 1984 to 2008 :

$$
\begin{aligned}
& \text { envpat } \text { / }_{\text {totdiesel }}=\alpha+\beta_{1}\left(P U B R \& D_{t}\right) \\
& +\beta_{2}\left(\text { diep OECD }{ }_{t}\right)+\beta_{3}\left(\text { StaNox JP }_{t}\right) \\
& +\beta_{4}\left(\text { StaNox }_{U}\right)+\beta_{5}\left(\text { EuroNox }_{t}\right) \\
& +\beta_{6}\left(E U V A_{t-1}\right) \\
& +\beta_{7}\left(\text { EUsales }_{t-1}\right)+\beta_{8}\left(\text { FedUS }_{t}\right) \\
& +\beta_{9} \text { timetrend }+\varepsilon_{t}
\end{aligned}
$$

where, envpat is the percentage of successful patents for pollution abatement; totdiesel is defined in eq. 1; $R \& D$ is research and development funding in transport in the OECD; diepOECD is diesel prices in the OECD; StaNOxJP is the Japanese emissions standard; StaNoxUS, is the US NOx emissions standard; Euro NOx is the EU emissions standard; EUVA and EUsales are as in equation 1; FedUS is the US Treasury bill rate; $t$, is a continuous time variable covering 1984 to 2008. Annual data is used throughout.

Our third equation tests the factors of growth of innovations of diesel engines. It is constructed in accordance with the linear and quadratic explanatory variables detailed in Table 4 . This model introduces a lag operator $(R \& D)_{t-k}$ which is varied between two and four years $(0<k \leq 4)$. The dependent variable is measured in the annual number of patents (Table 1).

\section{Results: factors for engine efficiency and air pollution innovation}

Results are shown in Tables 2 to 4. Equation 1 (Table 2) can be interpreted as the propensity of firms to innovate in diesel engine efficiency. This can be explained by market size (diesel cars in the EU and trucks in Japan), the effect of the fuel economy standards (EU Voluntary Agreement of 1995), and by a time trend. This suggests that the EU Agreement impacts engine efficiency innovation by giving incentives to develop better technologies (i.e. direct engine injection) that can lower costs of energy efficiency measures. This reduces $\mathrm{CO}_{2}$ emissions and abatement costs. The effects of two variables (Table 2) - public R\&D and oil prices - do not help explain the change in the propensity of firms to develop diesel engine efficiency, although equation 1 only includes the effect of public R\&D finance on innovation.

Table 2 shows that the propensity of firms to innovate in diesel engine efficiency is partly and positively correlated with a 'home market size effect'.This applies to Japan and the EU, but not to the US, possibly because Japanese firms are innovating for the EU diesel car market as well as for their own. The positive coefficient, of truck sales confirms that expected markets are important in influencing whether a $R \& D$ programme should receive funding. The propensity of firms to innovate in efficient diesel engines is weakly linked to lower loan rates in Japan; the coefficient is not statistically significant.

A firm's propensity for innovation in pollution control is reduced by the effects of EU diesel car sales and public R\&D (Table 3, Eq. 2). The effect of car market size on innovation is not positive because pollution control innovations preceded the development of the vehicle market. The impact of public R\&D funding crowds-out pollution control innovations. The effect of diesel prices, inclusive of taxes, is nonpositive. High prices discourage vehicle buyers, and in turn, this reduces the demand for innovation of pollution controls. This result confirms that diesel price, and a growing truck and car market, are weak tools 
Final version appeared as: D. Bonilla, JDK. Bishop, CJ. Axon, \& D. Banister (2014). Innovation, the diesel engine and vehicle markets: Evidence from OECD engine patents. Transportation Research Part D, 27, pp. 51-58, DOI: 10.1016/j.trd.2013.12.012.

since they have no effect on the propensity for innovation in pollution control technologies (Table 3). They relate to non-energy saving innovations.

Table 3 shows that pollution control innovations in Japan and the US responded positively to the introduction of NOx emissions standards, although the effect of the Euro-NOx emissions standard is weaker. The NOx standards have a consistently positive impact on innovation. The effect of the EU Voluntary Agreement on pollution control innovation also shows the correct sign since there is usually a trade-off between improving fuel economy (engine design) and pollution control technologies. Firms' propensity for pollution control innovation is also associated with the availability of finance reflected by the loan rate coefficient (Table 3).

Table 4 shows the results of the factors which influence the growth of innovations of diesel engines. The non-linear terms describe the effects of public R\&D. Engine innovation responds to three factors: public R\&D (with several lags), market size (EU car markets), and to diesel price (including taxes). Government actions (US CAFE and taxes on diesel in the EU) do enhance innovation and so does the ability to finance innovation (Table 4). Introducing the non-linear terms gives a positive association between public R\&D and innovation. The remaining explanatory variables are statistically significant (Table 4).

Table 2. Results: Propensity for diesel engine efficiency innovation, 1974 to 2008.

\begin{tabular}{lr}
\hline Independent Variable & \\
\hline Public R\&D (transport) (one year lag) & $0.10 *$ \\
Oil price & 0.001 \\
EU ratio: diesel cars to car sales (1 year lag) & $1.98 * * *$ \\
Japanese sales of trucks and buses & $0.60 * * *$ \\
Loan rate (Japan) & -0.23 \\
EU voluntary fuel efficiency agreement (one year lag) & $0.70^{* * *}$ \\
Time trend & $2.77 * * *$ \\
\hline$* * *$ Statistical significance at less than 1\%,** at less than 5\%; $*$ at less than $10 \% . \mathrm{R}^{2}: 0.70 ;$ \\
DW: 1.39, Coefficients represent the standard deviation change in the dependent variable \\
after one standard deviation shift in the independent one.
\end{tabular}

Table 3. Results: Propensity for emissions control innovation, 1984 to 2010.

\begin{tabular}{lr}
\hline Independent variable & $-0.70 * * *$ \\
\hline Public R\&D (Transport) & $-0.52^{*}$ \\
Diesel price (OECD avverage) & $0.252^{*}$ \\
Japan's Sta.-NOx emissions (parts/million) & 0.44 \\
US Sta.-NOx-HC standards (kg/km) & 0.176 \\
EURO NOx & $-0.542^{*}$ \\
EU Voluntary Agreement with car makers & $-1.71^{* *}$ \\
EU ratio diesel to car sales (two year lag) & $-0.58^{* *}$ \\
US Treasury bill rate (secondary market discount) & $3.3 * * *$ \\
Time trend & \\
\hline$* * *$ Statistical significance at less than 1\%, ** at less than 5\%; $*$ at less than $10 \% . \mathrm{R}^{2}: 0.724 ;$ \\
DW: 1.95
\end{tabular}


Final version appeared as: D. Bonilla, JDK. Bishop, CJ. Axon, \& D. Banister (2014). Innovation, the diesel engine and vehicle markets: Evidence from OECD engine patents. Transportation Research Part D, 27, pp. 51-58, DOI: 10.1016/j.trd.2013.12.012.

Table 4. Results: Growth of engine efficiency innovation; 1984 to 2010.

\begin{tabular}{lr}
\hline Independent variable & $0.44 * * *$ \\
\hline Public R\&D & $0.2^{* *}$ \\
R\&D (two year lag) & $0.67 * *$ \\
R\&D (three year lag) & $0.52^{* *}$ \\
R\&D (four year lag) & $-0.89^{* * *}$ \\
R\&D three year lag (quadratic term) & $-0.53^{* *}$ \\
R\&D four year lag (quadratic term) & $0.26^{* *}$ \\
Diesel prices (tax inclusive, OECD Average) & $0.68^{* * *}$ \\
EU sales: diesel vehicle (ratio of vehicle sales) & $0.17 *$ \\
US café (mpg) & $0.31^{* *}$ \\
Loan rate (Japan) & $-0.32^{* *}$ \\
Time trend & \\
\hline$* * *$ Statistical significance at less than $1 \%, * *$ at less than $5 \% ; *$ at less than $10 \% . \mathrm{R}^{2}: 0.98 ;$ \\
DW: 2.39.
\end{tabular}

\section{Innovation intensity}

The ratio of patents for diesel engine per thousand USD of public R\&D expenditure has been highly volatile. After growing between 1975-1990 (Figure 6), it fell in the early 1990s, and recovered in 2005. This trend indicates that the multiplier effect of public R\&D expenditure is increasing. It also indicates that it is becoming easier over time to innovate in engine technologies. Two points can be drawn from Figure 6. First, that the productivity of public R\&D improved but only slowly in the last two decades. Secondly, that the point at which returns to investment in public R\&D diminish has not been reached, thus further increases in public R\&D are worthwhile.

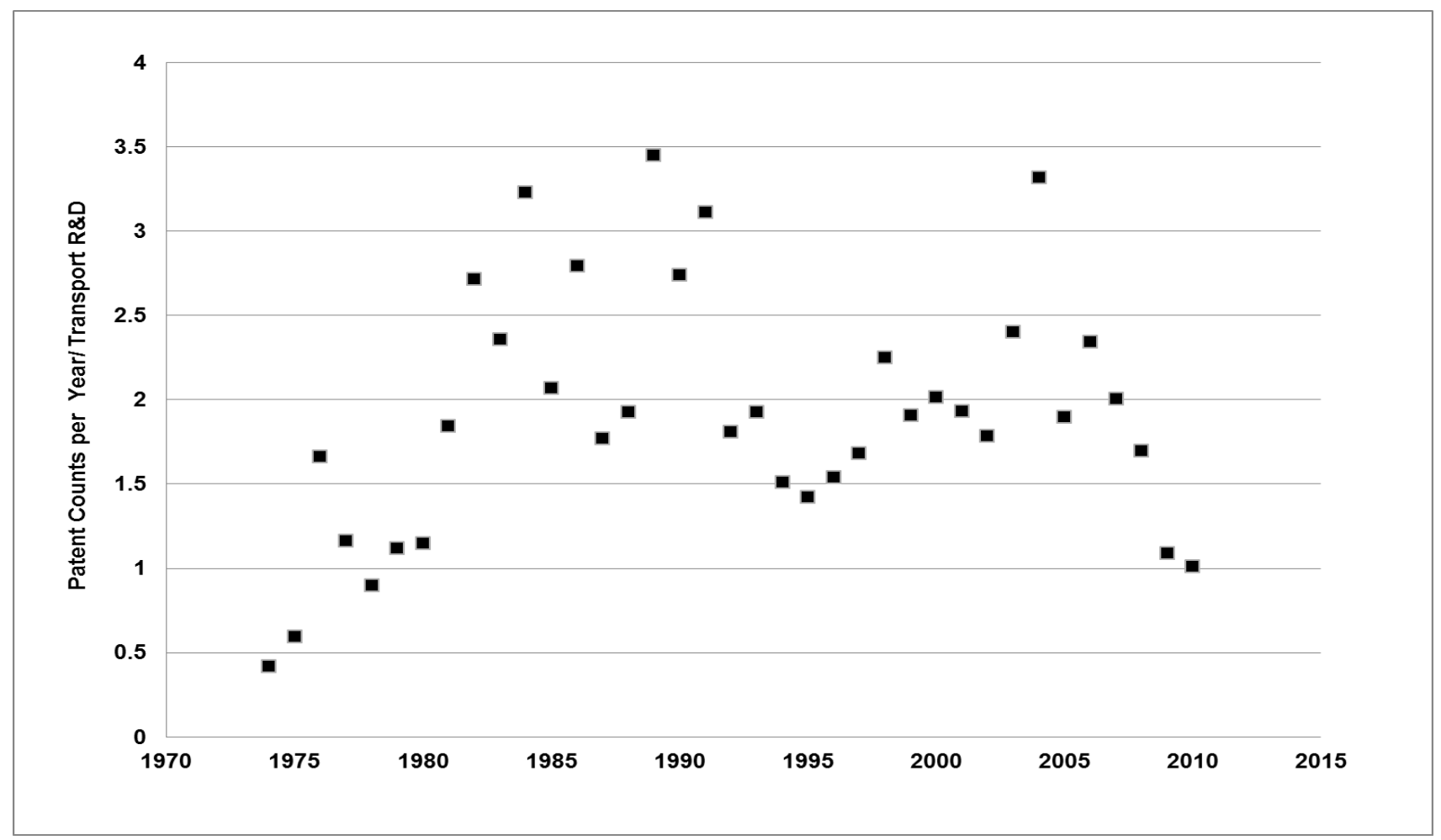

Figure 6. Innovation intensity (patents per public R\&D expenditure in \$millions at 2011 prices. Source: Based on International Energy Agency (2012); European Patent Office (2012). 
Final version appeared as: D. Bonilla, JDK. Bishop, CJ. Axon, \& D. Banister (2014). Innovation, the diesel engine and vehicle markets: Evidence from OECD engine patents. Transportation Research Part D, 27, pp. 51-58, DOI: 10.1016/j.trd.2013.12.012.

\section{Conclusions}

Our time-series model uses a large scale dataset. It shows that the propensity of firms to be innovative in diesel engine efficiency is explained by: loan rates, fuel economy standards, and the expanding car and truck markets of key countries. A firm's propensity to improve pollution control techniques, however, is crowdedout by transport R\&D funding. The introduction of air pollution standards is associated with increases in pollution control innovations. The EU Voluntary Agreement does not spur pollution control innovation because of trade-offs between improving fuel economy and pollution control technologies. Equally, fuel prices and car market size do not accelerate this type of innovation, while access to cheap finance does support pollution control innovation.

The analysis of the factors that explain the growth of innovation by firms in engine efficiency shows a positive non-linear effect of public R\&D, but the effect of public R\&D is less influential. The role of private R\&D funding is likely to be as important; our model provides evidence regarding the role of public R\&D funding. This category of innovation activity is dominated by private firms that are naturally conscious of market factors. The evidence confirms that engine efficiency innovation is induced by fuel prices and the CAFE limits. Future work should assess radical engine innovations along with actions of specific firms inside regional clusters of innovation.

\section{Acknowledgements}

The authors gratefully acknowledge the funding provided for this work by the Oxford Martin School, Oxford University as part of the ICERT initiative.

\section{References}

Bank of Japan Statistics 2012. "The Basic Discount Rate. 1973-2012 http://www.boj.or.jp/en/statistics/boj/other/discount/index.htm/_(Downloaded on 20 Dec. 2012).

Bonilla, D. 2009. Fuel demand on UK roads and dieselisation of fuel economy. Energy Policy, 37, 37693778.

Crabb , J. M., Johnson, D. K. N. 2007. Fuelling the innovative process: oil prices and induced innovations in automotive energy efficient technology. Working paper, Colorado College, College of Business and Economics.

Eurostat (2012) Eurostat statistics. Available at: http://epp.eurostat.ec.europa.eu/portal/page/portal/eurostat/home/

European Commission 2008. EC directive of the European parliament and of the council of the 21 may, 2008 on ambient air quality. Downloadable:

http://eurex.europa.eu/LexUriServ/LexUriServ.do?uri=OJ:L:2008:152:0001:0044:EN:PDF

European Patent Office, 2012. ESPACE. Downloadable at: http:// espace.net.com (January, 2012).

Davies, s., Diegel 2012. Transportation Energy Data Book: Edition 30. Oak Ridge National Laboratory, Center for Transportation Analysis. Oakridge TN.

Freeman, C., Soete, L. 1997. The Economics of Industrial Innovation. Routledge, Abingdon.

Hascic, I, De Vries, F., Johnstone, N., Neelakshi M., 2009. Effects of environmental policy on the type of innovation: The case of automotive emissions control technologies. OECD Journal: Economics studies. 49- 66

International Energy Agency 2012. Statistics Energy R \&D Database . 2012.

International Energy Agency 2011a. IEA Guide to European Patent Officerting R\&D\&D Budget expenditure statistics. IEA. Paris

International Energy Agency 2011b. Energy Prices and Taxes. Paris (various issues)

Institute of Energy Economics 2010, EDMC (Energy Data and Modelling Center). The Energy Conservation Centre, Tokyo.

Japan Automobile Manufacturers Association, 2012. The Motor Industry of Japan. Report,. Tokyo. Downloadable at Available at:// www.jama-english.jp.

Joint Research Center 2003. Dynamics of the Introduction of New Passenger Car Technologies. The IPTS Transport Technology model.. Report by Christidis P., Hidalgo, I., Soria, A. downloadable at: ftp://139.191.159.34/pub/EURdoc/eur20762en.pdf. 
Final version appeared as: D. Bonilla, JDK. Bishop, CJ. Axon, \& D. Banister (2014). Innovation, the diesel engine and vehicle markets: Evidence from OECD engine patents. Transportation Research Part D, 27, pp. 51-58, DOI: 10.1016/j.trd.2013.12.012.

Lutsey, N. 2012, Comparison of emissions, energy and cost impacts of diesel and hybrid models in the United States in 2010, Paper presented to the $90^{\text {th }}$ Annual Meeting of the Transportation Research Board, Washington DC

Newell, J., Jaffe, R.N., Stavins, R., 1999. The Induced Innovation Hypothesis and the Energy Saving Technological Change. Quarterly Journal of Economics 144, 941-975.

OECD 2009. Fuel taxes, motor vehicles standards and patents related to the fuel efficiency and emissions of vehicles". Free documents, Environment Directorate, OECD. Downloadable at the www.oecd.org/evn/taxes.

OECD 2011. Innovation and the Transfer of Environmental Technologies. OECD Studies of Environmental Innovation, Paris.

Popp , D., 2002. Induced Innovation and Energy Prices. American Economic Review 91 160-180.

Porter, M. E. 1991. America's Green Strategy. Scientific American. April, 168 Economics Readings. Penguin Books, London.

US Environmental Protection Agency, 2013 light duty automotive technology, carbon dioxide emissions and fuel economy trends: 1975-2012. Available at : http://www.epa.gov/otaq/fetrtwends.htm\#report

US Federal Reserve Bank 2012. Table H.15 selected interest rates. Data: 1970-2012.

US Department of Transportation 2012. Summary of fuel economy performance. Washington, DC.

Yergin, D. 2010. The Quest: Energy Security and Remaking of the Modern World. Allen Lane, London 